\title{
Multiplex polymerase chain reaction-based serotype analysis of dengue virus during 2015 dengue outbreak in Pakistan
}

Eijaz Ghani ${ }^{1}$, Saadiya Mushtaq ${ }^{1}$ and Saleem A. Khan ${ }^{2}$

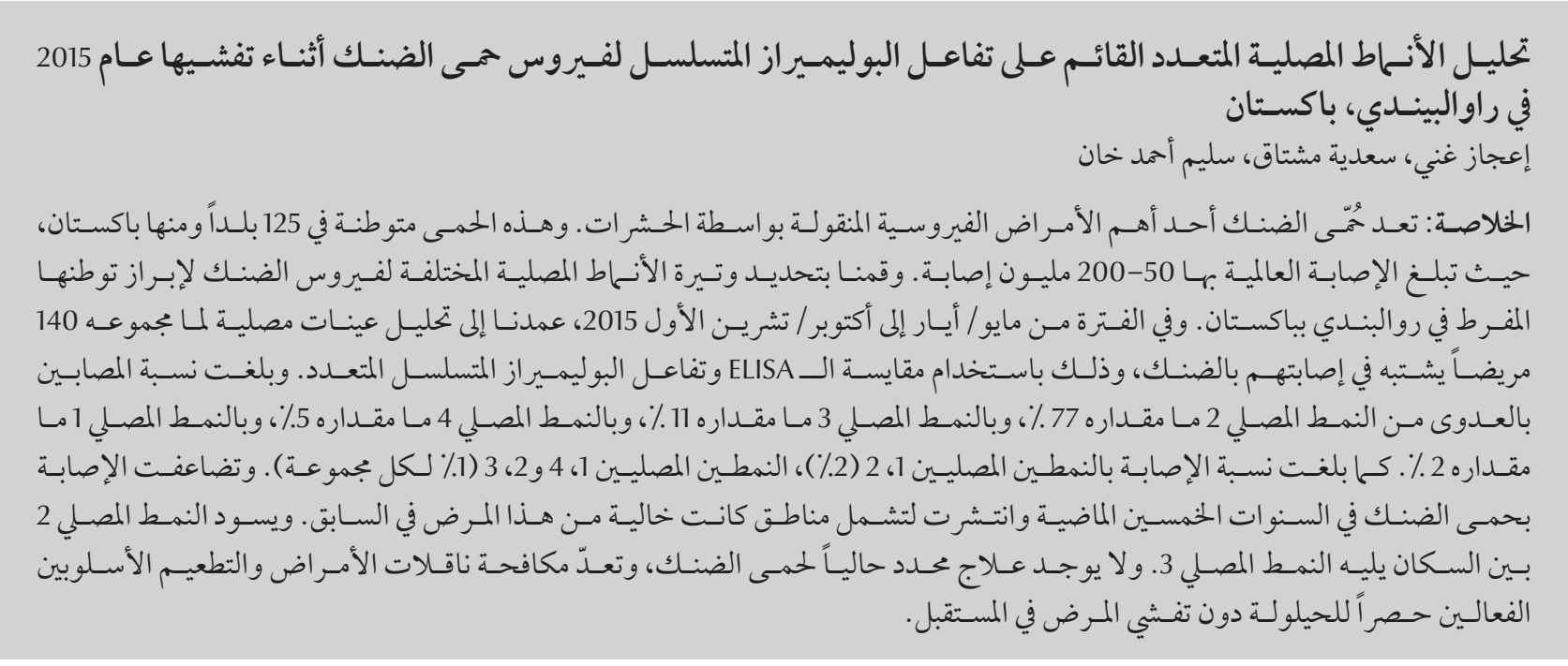

ABSTRACT Dengue is one of the most important arthropod-borne viral diseases. It is endemic in $>125$ countries including Pakistan, with a global incidence of 50-200 million. We determined the frequency of different serotypes of dengue virus to highlight its hyperendemicity in Rawalpindi, Pakistan. Between May and October 2015 we analysed the serum samples of 140 patients with a suspicion of dengue, using ELISA and multiplex polymerase chain reaction. One hundred and eight were infected with serotype 2, 16 with serotype 3, 7 with serotype 4 and 3 with serotype 1. Three patients were infected with serotypes 1 and 2 , and 1 each with serotypes 1 and 4 and serotypes 2 and 3 . Incidence of dengue has increased many fold in the past 50 years and has expanded to areas that were previously free from the disease. Serotype 2 was predominant in our population followed by serotype 3. There is currently no specific treatment for dengue, and vector control and vaccination are the only effective methods to prevent future outbreaks.

\section{Analyse des sérotypes du virus de la dengue par amplification en chaîne par polymérase multiplexe pendant la flambée de dengue de 2015 à Rawalpindi (Pakistan)}

RÉSUMÉ La dengue est l'une des plus importantes maladies virales transmises par des arthropodes. Elle est endémique dans plus de 125 pays dont le Pakistan, l'incidence mondiale étant comprise entre 50 et 200 millions. Nous avons déterminé la fréquence des différents sérotypes du virus de la dengue pour mettre en évidence son hyperendémicité à Rawalpindi (Pakistan). Les échantillons de sérum de 140 patients susceptibles d'avoir contracté le virus de la dengue ont été analysés entre mai et octobre 2015 à l'aide du test ELISA et de l'amplification en chaîne par polymérase multiplexe. Cent huit patients étaient infectés par le sérotype 2, 16 par le sérotype 3, sept par le sérotype 4 et trois par le sérotype 1 . Trois patients étaient infectés par les sérotypes 1 et 2 , un patient par les sérotypes 1 et 4 et un autre par les séroptypes 2 et 3. L'incidence de la dengue a considérablement augmenté ces 50 dernières années et elle s'est étendue à des zones qui étaient précédemment exemptes de la maladie. Le sérotype 2 était prédominant dans notre population suivi par le sérotype 3. II n'existe actuellement aucun traitement spécifique pour la dengue. La lutte antivectorielle et la vaccination constituent les seules méthodes efficaces pour prévenir les flambées futures. 


\section{Introduction}

Dengue virus infection has emerged as one of the most important arthropodborne viral diseases worldwide (1). It is endemic in $>125$ countries including Pakistan (2,3). Globally, there are 50-100 million cases of dengue fever and 500000 of dengue haemorrhagic fever (DHF) reported annually (4). The first recorded symptoms of dengue were reported in the Chinese Medical Encyclopedia in the year 992 (5). It was called a water poison then, however, the viral aetiology and transmission by mosquitoes were discovered in the 20th century after the major outbreak in World War II $(4,5)$. The first case of dengue was documented in Pakistan in 1994 in Karachi and the first outbreak occurred there in 2005 (6-8). The first case was documented in 1998 in the Armed Forces Institute of Pathology (AFIP), Rawalpindi.

Dengue is caused by dengue virus complex, which consists of 4 antigenically and immunogenically distinct serotypes, DENV1, DENV2, DENV3 and DENV4 that belong to the family Flaviviridae (6,7). Primary dengue infection with 1 serotype provides lifelong immunity to the infecting type, however, secondary infection with a heterologous serotype predisposes the patient to complications like DHF and dengue shock syndrome (DSS) due to nonneutralizing-antibody-dependent enhancement of the disease $(8,9)$. Dengue virus is a single-stranded positive-sense RNA virus whose genome encodes 3 structural proteins, capsid (C), precursor of membrane (prM) and envelope (E) and 7 nonstructural proteins, NS1, NS2A, NS2B, NS3, NS4A, NS4B and NS5 (10). Only E and NS1 proteins bear virus neutralization epitopes and play an important role in protective immunity. However, only NS1 is produced in both membrane-associated and secreted forms and expressed by all serotypes $(8-10)$. It is present in high concentrations early in the course of the disease in the sera of infected patients and is therefore used as a diagnostic marker in clinical practice (11).

Dengue virus is transmitted to humans through bites from infected female mosquitoes, Aedes aegypti and Aedes albopictus (12). The only vertebrate hosts of dengue virus in nature are humans and several species of Asian and African subhuman primates (13). The virus originates in the sylvatic cycle and is transmitted initially to a rural and then an urban cycle $(12,13)$. The 5th serotype of dengue virus, which was discovered in 2011, is currently confined to the sylvatic cycle, however, it is hypothesized that it will be transmitted from nonhuman primates to humans in the coming years like the other serotypes are (14). Transmission of dengue virus has increased markedly in recent years especially in the Americas, Southeast Asia and the Western Pacific (15). It is believed that dengue virus was first introduced to Pakistan through importation of tyres containing eggs of infected mosquitoes at Karachi sea port (16).

The objective of this study was to determine the frequency of different serotypes of dengue virus among patients with dengue fever, DHF or DSS during the 2015 outbreak in Rawalpindi. The variables investigated were age group and sex most commonly affected during this outbreak and the frequency of the respective serotypes.

\section{Methods}

From May to October 2015, we collected and analysed the clinical and laboratory data of 140 patients [121 (86\%) male and 19 (14\%) female, mean age 34 years]. The presence of dengue virus infection was determined in patients with suspicion of dengue fever who were referred to the Virology Laboratory, AFIP, Rawalpindi, Pakistan, and in hospitalized patients whose samples were sent for testing from the special dengue wards of mainly 2 tertiary care teaching hospitals in Rawalpindi, after obtaining informed consent. The study was approved by the Ethics Committee of the AFIP.

Serum samples that tested positive for NS1 antigen by ELISA were processed by multiplex polymerase chain reaction (PCR) in which the presence of all 4 serotypes (DENV1, DENV2, DENV3 and DEN4) was detected simultaneouslyusing 4 primer-probe sets in a single reaction mixture. RNA was isolated from the serum by automated extractor (Neosense; Euro Genomas, Vilnius, Lithuania). Dengue virus RNA in the patient samples was amplified using the Sacace Dengue Real Time PCR Kit and thermal cycler (Como, Italy), and the amplified products were detected using fluorescent dyes. These were linked to oligonucleotide probes that bound specifically to the amplified products. Serotype analysis was performed simultaneously on the same amplified products. The sensitivity of this assay was $98 \%$ and the specificity was $99 \%$.

We determined the frequency of different dengue virus serotypes in 4 different age groups, 1-20, 21-40, 41-60 and 61-80 years. We also determined the sex distribution of dengue virus serotypes.

Data were compiled and analysed using SPSS version 21 (SPSS Inc., Chicago, IL, USA).

\section{Results}

One hundred and eight (77\%) patients were infected with DENV2, which was the most common serotype found during this outbreak. The second most common was DENV3 with a frequency of $11 \%$ (16 patients). The frequency of DENV4 was 5\% (7 patients) and DENV 1 was present in $3(2 \%)$ patients. There were also some mixed infections with multiple serotypes of dengue virus. Three (2\%) patients were infected with 
DENV1 and 2, and 1 (0.7\%) each with DENV1 and 4 and DENV2 and 3 .

The most common DENV2 was present in 16 patients in age group $1-20$ years, 34 patients in age group 21-40 years, 22 patients in age group 41-60 years and only in 5 patients in age group 61-80 years (Figure 1). The age group most affected by any serotype was $21-40$ years.

\section{Discussion}

Dengue serotype analysis during a 2015 outbreak in Rawalpindi, Pakistan showed that serotype 2 was predominant in 108 patients, followed by serotype 3 in 16 patients, serotype 4 in 7 patients and serotype 1 in 3 patients. We also found mixed infections with dengue virus serotypes 1 and 2 in 3 patients, serotypes 1 and 4 in 2 patients and serotypes 2 and 3 in 1 patient.

Dengue fever has emerged as the most important arboviral infection in different geographical regions of the world (17). Pakistan has witnessed several outbreaks of dengue virus infection since 1994, which have led to significant morbidity and mortality in the past and imposed a great economic burden on the country $(16,18)$. The disease was initially restricted to Southern Pakistan, particularly Karachi, the capital of Sindh Province, and subsequently extended to cause major epidemics in Northern Pakistan as well (19). During 2006-2009, major dengue epidemics occurred in Karachi and the emergence of DENV3 in Pakistan was first reported during 2005 in a DHF outbreak in Karachi (18). Koo et al. conducted a study in Pakistan between 2006 and 2011 that showed that DENV3 was the predominant serotype (19). A major dengue epidemic was reported in 2011 in Lahore. Khan et al. conducted a study during that outbreak on 34 patients and showed that DENV2 was the predominant serotype (20).

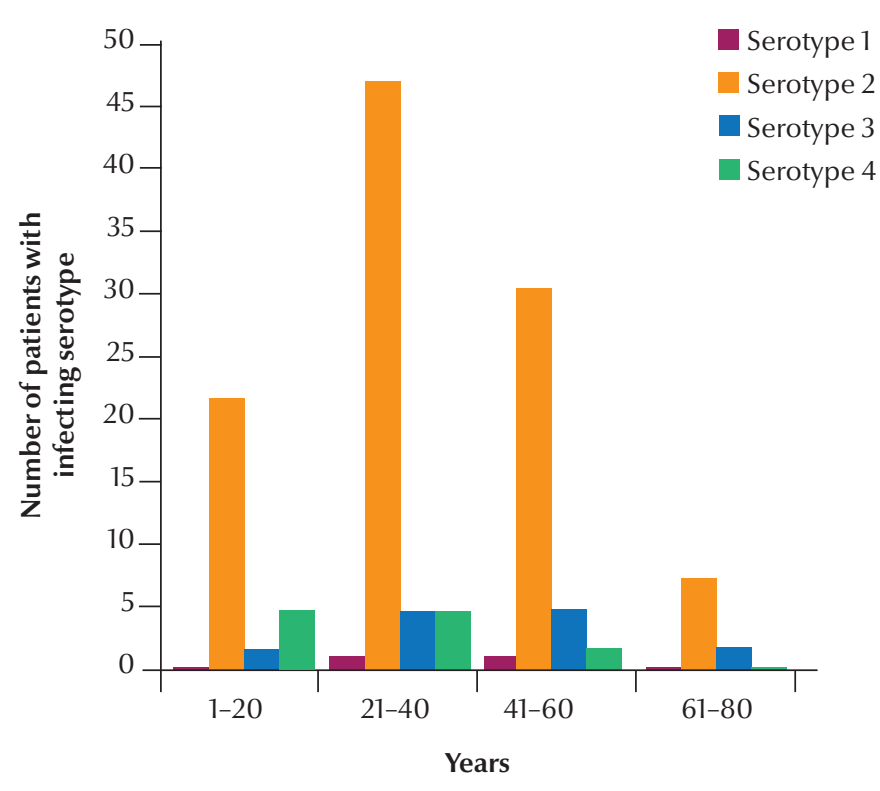

Figure 1. Frequency of dengue virus serotypes in different age groups during the 2015 outbreak in Rawalpindi, Pakistan.

We conducted the present study during the 2015 dengue outbreak in Rawalpindi, which is believed to be the first study in Pakistan on an adequate sample size (140 patients). Our study highlighted the hyperendemic potential of dengue virus in Pakistan by detecting the predominant DENV2 and the presence of the other three serotypes, which is alarming. There are not many data available on dengue virus serotypes in Pakistan and the predominance of DENV2 was not unexpected, as it is the most prevalent serotype worldwide and has been associated with severe epidemics (21). The outcome for patients in our study was good and neither young nor old were found to develop complications. Cocirculation of multiple dengue virus serotypes can result in major epidemics of severe disease. If these patients are re-infected with a heterologous dengue virus serotype, they are vulnerable to develop complications like DHF and DSS.

Many studies have reported the prevalent serotypes of dengue virus worldwide. Hansley et al. conducted a study in South America during 2005-2010 and reported the presence of DENV1 and 3 (22). A study from Lucknow, India in 2013 showed the presence of DENV1 and 3 (23). A Malaysian study also showed the prevalence of DENV1 and 3 (24).

For the correct molecular characterization of the virus, all the patient samples included in our study were collected during the acute phase of infection. Serum samples were used first for NS1 detection and those that tested positive were then used for viral RNA extraction. All samples that were positive for NS1 antigen were positive by PCR as well. So, NS1 antigen positivity is a good surrogate marker of dengue virus viremia because NS1 antigen is expressed by all 4 dengue virus serotypes.

Our study had some limitations. It was conducted in a single centre and in 1 city. In future, patients from all virology reference centres in different cities of Pakistan should be included for a better analysis of prevailing dengue serotypes in Pakistan.

In South Asia, all dengue serotypes have circulated periodically (25). The current study concluded that the predominant serotypes of dengue virus circulating in Rawalpindi are DENV2 
followed by DENV3. A significant number of cases with mixed serotypes were seen and might be common in all regions of the country. This hyperendemicity is indicative of a large outbreak of DHF in the future, so prevention of dengue fever and control of its vectors has become increasingly important.
Apart from sustainable vector control, timely diagnosis and case management is crucial for early recognition of DHF, especially in patients with a history of dengue fever. It had been hoped that the tetravalent vaccine that was in phase III clinical trials would bring an end to dengue virus disease. However, the vaccine suffered a setback because of the discovery of a 5th serotype of dengue virus (14). Much effort needs to be made to develop a holistic approach to control this disease in the future.

\section{Funding: None.}

Competing interests: None declared.

\section{References}

1. Gubler DJ. Epidemic dengue/dengue hemorrhagic fever as a public health, social and economic problem in the 21st century. Trends Microbiol. 2002 Feb;10(2):100-3. PMID:11827812

2. Gubler DJ. Dengue, urbanization and globalization: the unholy trinity of the 21(st) century. Trop Med Health. 2011 Dec;39(Suppl 4):3-11. PMID:22500131

3. TDR for Research on Diseases of Poverty. Dengue. Geneva: World Health Organization; 2017 (http://www.who.int/tdr/ diseases-topics/dengue/en/, accessed 23 May 2017

4. Gubler DJ. Dengue/dengue haemorrhagic fever: history and current status. Novartis Found Symp. 2006;277:3-16. PMID:17319151

5. Gubler D. The emergence of epidemic dengue fever and dengue hemorrhagic fever in the Americas: a case of failed public health policy. Rev Panam Salud Publica. 2005 Apr;17(4):221-4. PMID:15969972

6. Ilyaa M, Rahman Z, Shamas S, Alam M, Israr M, Masood K. Bioinformatics analysis of envelope glycoprotein e epitopes of Dengue virus type 3. Afr J Biotechnol. 2011;10(18):3528-35 (https://www.ajol.info/index.php/ajb/article/view/93425).

7. Idrees M, Hussain W, ur Rehman H, un Nabbi Tayyab G, Afzal $\mathrm{S}$, Fatima Z. Dengue virus serotype 2 (DEN-2): the causative agent of 2011-Dengue epidemic in Pakistan. Am J Biomed Sci. 2012;4:307-15 (http://www.nwpii.com/ajbms/papers/ AJBMS_2012_4_05.pdf).

8. Gubler DJ. Dengue and dengue hemorrhagic fever. Clin Microbiol Rev. 1998 Jul;11(3):480-96. PMID:9665979

9. Lee IK, Liu JW, Yang KD. Clinical characteristics, risk factors, and outcomes in adults experiencing dengue hemorrhagic fever complicated with acute renal failure. Am J Trop Med Hyg. 2009 Apr;80(4):651-5. PMID:19346394

10. Chamber TJ, Haln CS, Galler R, Rice CN. Flavivirus genome organization, expression and replication. Annu Rev Microbiol. 1990;44:649-88. PMID:2174669

11. Thomas L, Najioullah F, Verlaeten O, Martial J, Brichler S, Kaidomar S, et al. Relationship between nonstructural protein 1 detection and plasma virus load in Dengue patients. Am J Trop Med Hyg. 2010 Sep;83(3):696-9. PMID:20810841

12. Mukhtar M, Tahir Z, Baloch TM, Mansoor F, Kamran J. Entomological investigations of Dengue vectors in epidemic-prone districts of Pakistan during 2006-2010. Dengue Bull. 2011;35:99-115 (http://apps.who.int/iris/handle/10665/171002).

13. Sajid A, Ikram A, Ahmed M. Dengue fever outbreak 2011: clinical profile of children presenting at Madina Teaching Hospital Faisalabad. J Univ Med Dent Coll. 2012;3:42-7 (https://jumdc. tuf.edu.pk/articles/volume-3/no-1/JUMDC-8_Dengue.pdf).

14. Mustafa MS, Rasotgi V, Jain S, Gupta V. Discovery of fifth serotype of dengue virus (DENV-5): A new public health di- lemma in dengue control. Med J Armed Forces India. 2015 Jan;71(1):67-70. PMID:25609867

15. Suaya JA, Shepard DS, Siqueira JB, Martelli CT, Lum LC, Tan $\mathrm{LH}$, et al. Cost of Dengue cases in eight countries in the Americas and Asia: a prospective study. Am J Trop Med Hyg. 2009 May;80(5):846-55. PMID:19407136

16. Chan YC, Salahuddin NI, Khan J, Tan HC, Seah CL, Li J, et al. Dengue haemorrhagic fever outbreak in Karachi, Pakistan, 1994. Trans R Soc Trop Med Hyg. 1995 Nov-Dec;89(6):619-20. PMID:8594672

17. Dash PK, Parida MM, Saxena P, Kumar M, Rai A, Pasha ST, et al. Emergence and continued circulation of dengue-2 (genotype IV) virus strains in northern India. J Med Virol. 2004 Oct;74(2):314-22. PMID:15332281

18. Jamil B, Hasan R, Zafar A, Bewley K, Chamberlain J, Mioulet V, et al. Dengue virus serotype 3, Karachi, Pakistan. Emerg Infect Dis. 2007 Jan;13(1):182-3. PMID:17370547

19. Koo C, Nasir A, Hapuarachchi HC, Lee KS, Hasan Z, et al. Evolution and heterogeneity of multiple serotypes of Dengue virus in Pakistan, 2006-2011. Virol J. 2013 Sep 4;10:275. PMID:24007412

20. Khan MA, Ellis EM, Tissera HA, Alvi MY, Rahman FF, Masud $\mathrm{F}$ et al. Emergence and diversification of dengue 2 cosmopolitan serotype in Pakistan. PLoS One. 2011;8(3):e56391. PMID:23520453

21. Chaudhry S, Swaminathan S, Khanna N. Viral genetics as a basis of dengue pathogenesis. Dengue Bull. 2006;30:121-32 (http://apps.who.int/iris/bitstream/10665/170266/1/db2006v30p121.pdf).

22. Halsey ES, Marks MA, Gotuzzo E, Fiestas V, Suarez L, Vargas J et al. Correlation of serotype-specific dengue virus infection with clinical manifestations. PLoS Negl Trop Dis. 2012;6(5):e1638 (https://doi.org/10.1371/journal.pntd.0001638).

23. Tripathi SK, Gupta P, Khare V, Chatterjee A, Kumar R, Khan MY et al. Emergence of new lineage of Dengue virus 3 (genotype III) in Lucknow, India. Iran J Microbiol. 2013 Mar;5(1):68-75. PMID:23466682

24. Ab-Fatah M, Subenthiran S, Abdul-Rahman PS, Saat Z, Thayan $R$. Dengue serotype surveillance among patients admitted for dengue in two major hospitals in Selangor, Malaysia, 20102011. Trop Biomed. 2015 Mar;32(1):187-91. PMID:25801270

25. Humayoun MA, Waseem T, Jawa AA, Hashmi MS, Akram J. Multiple dengue serotypes and high frequency of dengue hemorrhagic fever at two tertiary care hospitals in Lahore during the 2008 dengue virus outbreak in Punjab, Pakistan. Int J Infect Dis. 2010 Sep;14(Suppl 3):e54-9. PMID:20171916 